\title{
Difficulties related to work in the certification process for organic production
}

\author{
S. F. B. Gemma ${ }^{1 *}$ \\ Ergonomics and Occupational Health, School of Applied Sciences, University of Campinas, Brazil
}

\begin{abstract}
This study discusses issues related to work in the certification process of Organic Production Units (OPU). Data was collected from ten producers in the region of Campinas, Sao Paulo Brazil, which represent the majority of producers of certified organic vegetables and fruits. The methodology used was an adaptation of Ergonomic Work Analysis method, and structured interviews. As OPU are small and most people perform many tasks related to the various work systems, there is little specialization. Their activities are uncomfortable, awkward physical postures and significant efforts are necessary to perform the work in horticulture. Tasks are predominantly manual and just a few of them can count on the help of mechanization. The certification process and it's maintenance have several implications for farmers, on top of the paperwork, there is an universe of work already so full of activities demanded by the production and marketing systems. The complex context of production, mainly because of its diversity, associated with lack of financial resources and technology, demands from organic farmers to build multiple strategies for business survival. Certification can, contrary to what is expected represent another barrier to the expansion of organic production.
\end{abstract}

Keywords: organic agriculture, ergonomics, ergonomic work analysis, certification processes, certifiers

\section{Introduction}

Organic agriculture (OA) advocates a sustainable production in ecological, economic and social perspectives [11], as Altieri [9] says: "Agroecologybased production systems are biodiverse, resilient, energetically efficient, socially just and comprise the basis of an energy, productive and food sovereignty strategy". Since its inception in the 1920s, the OA has been developing rapidly and is already practiced in over 160 countries worldwide, with more than 37 million hectares, by approximately 1.8 million organic producers. Paull [8] demonstrates that "Australia accounts for $32.2 \%$ of the world's organic agriculture land, and the three lead countries, Australia Argentina and USA, together account for $49.3 \%$ of the world's organic agriculture land".

Brazilian market represents $1 \%$ of the global market, but it grows 30 to $50 \%$ every year (double of the global average) according to Brazilian Support Service for Micro and Small Enterprises (SEBRAE) [12].

Currently only $0.67 \%$ [8] of Brazilian land is managed organically, although the government has set a target of 20\% for the year 2012 [7]. Brazil is the third Latin American country in terms of organic area owning 880'000 hectares [5].

The Brazilian Institute of Geography and Statistics (IBGE) presents data for a diagnosis made by FOA / United Nations-UN in 2005, pointing to organic agriculture and the food industry with fastest growth between 1995 and 2005; it has grown from 15 to $20 \%$ per year, while the entire sector of food industry has grown between 4 and 5\% [1].

According to the Biodynamic Institute - IBD [6] the organic-sales in Brazil reached $\mathrm{R} \$ 350$ million in 2010, a figure that is $40 \%$ higher than in 2009 .

In 2006 , from a total of $5,175,489$ of agricultural establishments in Brazil, only 90,497 were engaged in organic agriculture, ie organic producers ac-

$1 *$ Address for correspondence: S.F.B. Gemma, Ergonomics and Occupational Health, School of Applied Sciences, University of Campina, R. Pedro Zaccaria, 1300 - Jd Santa Luiza - Cep.13.484-350, phone:+55 19 37016674, Limeira, SP, Brazil; E-mail:

sandra.gemma@fca.unicamp.br 
counted for approximately $1.8 \%$ of the total investigated. It should be noted that, from these, only 5,106 (5.64\%) are certified, leaving 85,391 out of this process. In Sao Paulo the total 227,594 establishments, only 3,371 are from organic agriculture, of which only 451 are certified (13.37\%). Regarding the size of production units, small prevails, as in the first place are establishments with a total area of 10 to less than 20 ha (978 establishments), secondly are those with total area of 20 to less than 50 ha (916 establishments), and in third place those between 5 and less than 10 ha (813 establishments) [1].

During the first five years of 2000 , considering the total organic production of Brazil, $60.0 \%$ were exported, mainly to Japan, the United States and the European Union and 30 other countries. Among the organic products exported, the highlights are fresh products and processed soy, sugar and rice (with a temporary rise in the crop), coffee and cocoa (with origins in the permanent crop), those from livestock and the creation of small animals (meat, dairy and honey) and extraction (mostly palm hearts).

Certification can be understood as a tool of the market, which should be properly regulated, to fulfill its original purpose, mainly to protect everyone involved in the production chain, such as consumers, producers and distributors. It can also serve as a guarantee of access to differentiated markets for producers. However, certification is only meaningful when the distance between producers and consumers so requires, as its main appeal is to create trust in an anonymous market [10].

For a product to be marketed as organic, the production unit must undergo a process of conversion from conventional to organic system, which usually takes about two years. This has been a major barrier to enter the market, because during this process there is a drop in production and the product is still unable to be sold as certified.

The conversion involves normative, biological and educational aspects. The normative, as the name suggests, are those related to official regulations for organic production. The biological aspects refer to the more technical part of the conversion, involving agronomic, veterinary, zoo technical and biological processes, including the rebalancing of insect population, soil conditions, the differentiation of the landscape and the need to reorganize the technical knowledge for the focus of ecology. Finally, the educational aspects are related to the learning of the concepts and management techniques typical of this production system needed by farmers and workers [4].
Although third-party audit certification process is predominant, it is relatively recent. According to Paull: "Worldwide, there are now 532 organic certifiers, and only 10 reporting that they have started before 1985" [8].

If from one perspective it is undeniable the need to assure the production quality for the society, in the other hand it is understood that this process must be studied under the agriculturists work perception. The deeper knowledge about the labor correlated requirements and about the consequent demands related to the number of tasks, as well as their difficulty and complexity degree are not available.

The surveys that aim to discuss issues related to work within this system are scarce. By studying the work of managers in organic agriculture from the perspective of ergonomics Gemma, Tereso and Abrahão [13] showed that there are many aspects of this industry that need to be improved and which need to be further deepened, in order to obtain elements that allow to assess, more effectively, the effects that this activity can have on working conditions and lives of people involved.

The focus of this study is to show, through the ergonomics of the activity, the labor issues related to the certification process.

\section{Method}

The data used in this study come from the doctoral thesis of the author of this article [14]. Data was collected from ten producers in the region of Campinas, Sao Paulo Brazil, which represent the majority of producers of certified organic vegetables and fruits.

The methodology used was an adaptation of Ergonomic Work Analysis method - AET [3], and structured interviews. From the three main phases of this method (demand analysis, task and activity), only the demand analysis was not performed, since there wasn't a demand socially made by the workers. Instead, demand was academic in nature, guided by the objectives of this research.

Initially, we used 72 hours of observation in the field to know the work of the farmers in two units of certified organic production of fruits and vegetables in the interior of Sao Paulo state. We studied in detail the activities of these OPU through general observations and open interviews. At this stage of observations, it was investigated what farmers were doing, how they did, why they were doing and, mainly, what difficulties and what strategies were used to overcome them. 
Later, in a second step, based on knowledge already acquired, a questionnaire was developed which was also applied to other organic production managers during interviews conducted from May to July 2007. We sought to determine whether the difficulties and strategies observed in the first two OPU were also present in other units.

Each interview lasted on average two and a half hours. Ten OPU managers that are located near the

\section{Results and discussion}

There is considerable variation among the Organic Production Units (OPU) in terms of total area (5 to 160ha) and cultivated area (4 to $33 \mathrm{ha}$ ), as well as the composition of the workforce (family and hired workers - Table 1). However, they may all be considered small compared to the conventional standards of the Brazilian agrarian structure.

In most OPU, besides crop production, there is animal production and processing of various items, and $40 \%$ of them also work for the service sector (tourism and events related to agroecology). Thus, only $30 \%$ of OPU focus exclusively on crop production.

The others, besides working with a wide variety of crops (average of approximately 34 items and up to $81)$, are also dedicated to livestock production $(50 \%$ OPU) and $70 \%$ of OPU does some kind of processing (minimum two and maximum of 12 items - Table 1).

Crop production is predominantly of vegetables followed by fruit and three OPU still grow grain. Livestock production, although only present in half of OPU, is varied, being eggs, milk and honey products the most prevalent.

In OPU was found that most people perform many tasks related to the various work systems, therefore there is little specialization. Exception occurs in those tasks involving the operation of tractors or machines, which are usually carried out by trained farmers for this purpose.

Their activities are uncomfortable. Awkward physical postures and significant efforts are necessary to perform the work in horticulture, especially during planting, cultivation and harvesting, as tasks are predominantly manual and just a few of them can count on the help of mechanization. city of Campinas and work with a production certified as organic were personally interviewed by the author.

It should be emphasized again that the number of respondents represents the majority of producers of certified organic vegetables and fruit within a radius of $90 \mathrm{~km}$ of Campinas, which gives an important weight to this research.

It is worth noting that the system of crop production involves several stages or subsystems, such as soil preparation, planting, cultivation, harvesting and processing/post-harvest. In turn, each subsystem consists on sets of tasks and sub tasks that need to be organized over time. The livestock production system involves tasks related to nutrition, reproduction, bio security (vaccines, cleaning products, medicines) and other management strategies (eg. shearing and dehorning). The wide variety of activities that was observed is related directly to the diversity of production, especially the crop production. The number of crops in both OPU initially surveyed, whose acreage was 4 and 12ha respectively, was 52 types of vegetable and strawberry in Jarinu and 67 types of vegetable and 16 types of fruit in Itu. It was evidenced that in order to produce so many items, the amount of information and knowledge that farmers must possess was quite significant, because each crop has different requirements. Added to this, they must also integrate these crops to livestock, plan them and distribute them over time, according to weather conditions and available space, as well as the demands and requirements from certifiers and customers.

As a result of interviews carried out during the research, it was found that most producers $(80 \%)$ believe that certification brings a lot of paperwork, 50\% of them that return given by the certifier is time consuming when making requests, and $40 \%$ of the rules or standards for certification are not very clear. Some say that some of the requirements of the certifiers are almost impossible to be met, or require too much work $(40 \%)$. 
Table 1

General data of OPU. Campinas Region, SP, Brazil

\begin{tabular}{|c|c|c|c|c|c|c|c|c|c|c|c|c|c|c|c|}
\hline \multirow{2}{*}{ OPU } & \multicolumn{4}{|c|}{ Localization and Area } & \multicolumn{7}{|c|}{ Human resources } & \\
\hline & & cuit. & & FI & PT & 1. & E & $\mathrm{S}$ & D & 1. & G.T & PL. & L. & P. & G.1 \\
\hline 1 & Itu & 12 & 30 & 2 & 0 & 2 & 12 & 0 & 2 & 14 & 16 & 81 & 2 & 12 & 95 \\
\hline 2 & Jarinu & 4 & 5 & 3 & 3 & 4,5 & 0 & 0 & 0 & 0 & 4,5 & 54 & 0 & 2 & 56 \\
\hline 3 & Jaguariúna & 33 & 60 & 18 & 1 & 18,5 & 14 & 0 & 0 & 14 & 32,5 & 60 & 1 & 4 & 65 \\
\hline 4 & Jarinu & 4 & 8,5 & 1 & & 1 & 2 & 0 & 0 & 2 & 3 & 4 & 0 & 0 & 4 \\
\hline 5 & Valinhos & 4 & 7 & 2 & 2 & 3 & 4 & 0 & 0 & 4 & 7 & 45 & 0 & 0 & 45 \\
\hline 6 & Jaguariúna & 9 & 14 & 4 & 1 & 4,5 & 0 & 0 & 1 & 1 & 5,5 & 25 & 0 & 7 & 32 \\
\hline 7 & St. A. Posse & 30 & 160 & 2 & 2 & 3 & 15 & 0 & 0 & 15 & 18 & 28 & 1 & 2 & 31 \\
\hline 8 & Indaiatuba & 18 & 36 & 1 & 1 & 1,5 & 3 & 11 & 0 & 14 & 15,5 & 26 & 4 & 3 & 33 \\
\hline 9 & Paulínia & 9,7 & 17 & 2 & 0 & 2 & 5 & 0 & 0 & 5 & 7 & 9 & 0 & 0 & 9 \\
\hline 10 & Serra Negra & 19 & 100 & 1 & 1 & 1,5 & 6 & 7 & 2 & 15 & 16,5 & 6 & 6 & 10 & 22 \\
\hline & verage & 14,3 & 43,7 & & & & & & & & 13 & 34 & 1 & 4 & 39 \\
\hline
\end{tabular}

OPU= Organic Production Unit; Cult. $=$ Cultivated area; $\mathrm{T}=$ Total area; FT=Full Time; $\mathrm{PT}=$ Part Time $(0,5$ Person $)$ E $=$ Employee; $\mathrm{S}=\mathrm{Share}-$ cropper; $\mathrm{D}=$ Diarist; $\mathrm{G} . \mathrm{T}=$ Grand Total; $\mathrm{PL}=$ Plant Production; $\mathrm{L}=$ Livestock Production; $\mathrm{P}=$ Processing.

One of the interviewees insisted on illustrating by showing one of the questionnaires that he needs to thoroughly complete before the inspection, and it contains 25 pages.

The data found on this research is similar to that found by Ahrens [2] which demonstrated that there was an information lack about the ecological management and that the administrative procedures linked to environmental legal matters are of great complexity to the producers.

In a previous research on organic fruit production analysis, even though the focus was in the bagging of fruits, Gemma, Sznelwar and Abrahão [15] also described some of the implications of the certification process for the producers, such as the need to fill lengthy purchase documents and spreadsheets for data control for traceability of production from planting to marketing.
From the general difficulties raised in the interviews, the following are highlighted: the physical effort $(80 \%)$; the uncomfortable and painful postures $(90 \%)$; the mental effort $(90 \%)$; the lack of technological resources to control pests and diseases $(80 \%)$ and to achieve the desired quality (80\%); the lack of technical assistance (70\%); those related to lack of financial resources associated with lack of access to credit $(80 \%)$ and the high cost of production $(80 \%)$; those related to human resources, especially to find qualified people (80\%) and people who remain in the field. Other difficulties reported were: decision making $(70 \%)$; profit $(70 \%)$; marketing handling $(60 \%)$; meeting certification standards, since they involve paperwork $(80 \%)$ and determining rules which are unclear or difficult to be met $(40 \%)$, besides its high cost $(60 \%)$.

Other researchers have reported some of these same difficulties in their studies $[11,15]$. 
With respect to the certification process and the relationship that farmers need to keep with the certifiers, we can highlight different aspects that provide a dimension of difficulties:

“... Every time a new ban comes up ... before we could use syrup of smoke, now it's forbidden... before the ban we could use bordalaise mixture, now only with permission of the certifier ... it seems that the certifier wants to end discretely the organic agriculture".

“... Almost every week a letter from the certification company comes with a new ban.”.

About the visits to verify the compliance audit, which is done periodically and in most cases by different specialists:

"It's too much trouble this certification business... every time a different auditor comes and we must tell everything all over again ... starting from scratch".

According to Azambuja [16] there are many criticisms concerning the use of compulsory certification by third party external audit (accreditation bodies) in order to guarantee the quality, production and marketing of organic products, as the certification programs do not differentiate between large and small producers, requiring similar efforts of inspection, regardless of the size of the production unit, which can cause unnecessary inspections for small producers.

The complex context of production, mainly because of its diversity, associated with lack of financial and technological resources of organic farmers demand the construction of multiple strategies for business survival.

The ecological sustainability implied by the organic management brings a great diversity to the work of farmers. They need to develop original strategies to face the difficulties of many varied nature, uncertainties and contradictions.

Besides the ecological sustainability, it is required that farmers ensure economic viability and maintain fair social and work relationships, to meet the other precepts of sustainability. To do so and properly manage the various types of production and protect natural resources, these farmers incorporate, integrate and more specifically "translate" these principles in agricultural practices, balancing sometimes dimensions which are so contradictory, such as ecological and economical.

\section{Conclusion}

In this study we found that The certification process and it's maintenance have several implications for the farmers, because the protocols and procedures to perform work as a prescription outside the production, which turns out to be so general to encompass all the items of the analysis, becomes difficult to understand and apply in each production unit with their respective peculiarities.

More bureaucratic tasks are added to the universe of farmers work already so full of activities related to production and marketing systems.

It is noticed a contradiction in dialogues extracted from farmers because the certification, which was supposed to help expanding the sector and bringing security, demand so much trouble, which is now seen as a barrier to expansion. Beyond the financial issues, this may in part explain the data shown in the introduction in which the number of non-certified organic farmers is higher when compared with the certified ones.

In this sense, the certification often ends up being seen as an impediment to the expansion of production, which it was supposed to be the opposite.

Much more research needs to be performed to remove obstacles and difficulties that are imposed on organic farmers, especially on technical, health and comfort issues, beyond those related to marketing, certification and access to credit. It also needs to develop public policies that foster care and adequate technical support. Only the integration of various efforts can contribute to the development of this sector, not only in terms of productivity and quality but also for improvements to work and quality of life of farmers.

The vision of work that ergonomics provide can contribute to expanding the body of knowledge of organic production in an attempt to load in itself the bases for a "more sustainable human work" in agriculture.

The organic agriculture is in a faster growing pace and any research that can add value to the analysis of this type of agricultural handling, apart from the conventional method, can collaborate to a more solid and structured development and probably more sustainable also from the perspective of those who perform the job. 


\section{References}

[1] Brasil, Ministério do Planejamento, Orçamento e Gestão, Instituto Brasileiro de Geografia e Estatística - IBGE, O Censo Agropecuário de 2006: Brasil, Grandes Regiões e Unidades da Federação, Issn 0103-6157, Rio de Janeiro, p. 1-

[2] DT.C., 201016ens, Rede de propriedades familiares agroecológicas uma abordagem sistêmica no Centro-Sul do Paraná, Londrina: Instituto Agronômico do Paraná, 2006.

[3] F. Guérin, A. Laville, F. Daniellou, J. Duraffourg, A. Kerguelen, Compreender o trabalho para transformá-lo: a prática da ergonomia, Sao Paulo: Edgard Blucher.Henz, 2001.

[4] G.P. Henz, F.A. Alcantara and F.V. Resende, Produção orgânica de hortaliças: o produtor pergunta, a Embrapa responde, Brasília: DF: Embrapa Informação Tecnológica,

[5] EDOW.iller, M. Yussefi and N. Sorensen (2008), The World of Organic Agriculture Statistics and Emerging Trends 2008, Retrieved august 15, 2011, from http://orgprints.org/13123/4/world-of-organic-agriculture2008.pdf.

[6] IBD - Instituto Biodinâmico, Mercado Interno de Orgânicos cresce $40 \%$, IBD News -2011 , Retrieved: February $23^{\text {th }} 2011$, from:

http://www.ibd.com.br/News_Detalhe.aspx?idnews=269.

[7] IFOAM - International Federation of Organic Agriculture Movements, 2005, Brazil Government Sets Sights High for Organic Agriculture, Retrieved: August 15, 2011, from http://www.ifoam.org/press/press/2005/Government_Brazil_S upports_Organic.php.

[8] J. Paull, Organics Olympiad 2011: Global Indices of Leadership in Organic Agriculture, Journal of Social and Development Sciences, Vol. 1, No. 4, pp. 144-150, May 2011, Retrieved: $\quad$ August $12^{\text {th }}$, 2011 from: http://www.ifrnd.org/JSDS/1\%284\%29\%20May\%202011/Org aics\%20Olympiad\%202011 Global\%20Indices\%20of\%20Le adership.pdf.
[9] M.A. Altieri and V.M. Toledo, The agroecological revolution in Latin America: rescuing nature, ensuring food sovereignty and empowering peasants, The Journal of Peasant Studies. Vol. 38, No. 3, July 2011, 587-612.

[10] M.C.P Neves, Produção, Mercado e Certificação de Produtos Orgânicos, ISSN 1517-8498, EMBRAPA Agrobiologia. Seropédica - RJ: 2005.

[11]M.R. Darolt, Agricultura orgânica: inventando o futuro, Londrina: IAPAR, 2002.

[12] SEBRAE (Serviço Brasileiro de Apoio às Micro e Pequenas Empresas) 2005, Brasil prepara-se para receber a Biofach com números recordes, Agência Sebrae de Notícias, 03/03/2005, Retrieved:18 out. 2005, from http://asn.interjornal.com.br/site/noticia.kmf?noticia=2874949 \&canal $=206$.

[13] S.F.B. Gemma, M.J.A. Tereso and R.F. Abrahão, Ergonomia e complexidade: o trabalho do gestor na agricultura orgânica na região de Campinas - SP, Ciência Rural (UFSM. Impresso), p. $318-324,2010$

[14] S.F.B. Gemma, Complexidade e agricultura: organização e análise ergonômica do trabalho na agricultura orgânica, 280p. Thesis in Agricultural Engineering from the School of Agricultural Engineering, University of Campinas, Campinas- SP, Brazil, 2008

[15] S.F.B. Gemma, R.F. Abrahão and L.I. Sznelwar , O Trabalho no Cultivo Orgânico de Frutas: Uma Abordagem Ergonômica Revista Brasileira de Saúde Ocupacional, Sao Paulo, v. 29, n. 109 , p. 37-44, 2004.

[16]S. P. Azambuja, Representações e práticas sócio-ambientais: o caso dos agricultores ecologistas da AECIA. 257p, Dissertation. UFRGS, School of Economic Sciences. Porto Alegre, 2005. 